\title{
JURISPRUDENGE
}

\section{Penal and Legal Doctrine as a Legal Category and a Metalanguage Means to Shape the Penal and Legal Policy}

\author{
VITALII E. LAPSHIN \\ Vladimir State University Named After Alexander and Nikolay Stoletovs, Vladi- \\ mir, Russian Federation, Vladimir Law Institute of FSIN Russia, Vladimir, Russian \\ Federation, Vologda Institute of Law and Economics of FSIN Russia, Vologda, \\ Russian Federation
}

ORCID: https://orcid.org/0000-0002-6243-9532, e-mail: ve_lapshin@mail.ru

\section{VYACHESLAV V. SHAKHANOV}

Vladimir Branch of the Russian Academy of National Economy and Public Administration under the President of the Russian Federation, Vladimir, Russian Federation, Vladimir Law Institute of FSIN Russia, Vladimir, Russian Federation

ORCID: https://orcid.org/0000-0003-1251-7886, e-mail: shakhanov.vyacheslav@ mail.ru

Abstract. So far, the science of penal law has not looked closely into the term "doctrine", and, in particular, "penal and legal doctrine" from the theoretical point of view. Thus we find it necessary to eliminate this gap, since the use of these terms and their synonyms varies greatly in the scientific and educational activities of penal institutions. Understanding the doctrinal grounds is also important for assessing the current situation and prospects for development of the science of penal law. The article analyzes the usage of the terms "penal and legal doctrine", "criminal-executive doctrine" "doctrine of criminal-executive law", "penal doctrine", "correctional doctrine"; penal and legal doctrine is considered as part of legal doctrine; we study the notion of "legal doctrine" in its relations with adjacent categories (science, concept, position); we also investigate the effects of penal and legal doctrine on the penal and legal policy. We conclude that the term "penal and legal doctrine" is the core one and acts as a necessary prerequisite for scientific analysis. We also provide recommendations for the use of the term "doctrine" in the penal law sphere and put forward our own definition of the term "penal and legal doctrine". In the course of our research we used general scientific, sectoral (social narrative) and level methodology (methods of theoretical and metatheoretical levels of cognition in science).

Key words: penal and legal doctrine; legal doctrine; criminal-executive doctrine; correctional doctrine; doctrine of the criminal-executive law; penal and legal policy; metalanguage tool.

12.00.01 - Theory and history of law and state; history of law and state.

For citation: Lapshin V.E., Shakhanov V.V. Penal and legal doctrine as a legal category and a metalanguage means to shape the penal and legal policy. Penitentiary Science, 2020, vol. 14, no. 4 (52), pp. 537-541. DOI 10.46741/2686-9764-2020-14-4-537-541.

Any scientific research, as a rule, starts with an analysis of the terminology it uses, because, according to a well-known scientific axiom, "before you start a debate, you need to de- fine the terms". It is worth paying attention to the terms that act as metalanguage means, which may not be generic (specific) or related concepts and categories, but may be system- 
forming and considered as a necessary prerequisite for scientific analysis. These include the term "doctrine" (in the penal sphere:"penal doctrine", "criminal-executive doctrine", "doctrine of the criminal-executive law", etc.).

Having analyzed the information on the official website of the Federal Penitentiary Service of Russia (FSIN Russia), we find the following phrases with the term "doctrine": "religious doctrine", "pre-revolutionary legal doctrine", "military doctrine", "doctrine of uncertainty in law", "doctrine of military science", "doctrine of criminal punishment", "food security doctrine", "information security doctrine", "political and legal doctrine of the state", "correctional doctrine", etc. As we can see, the term "doctrine" is quite variable. It is used in the scientific and public life of research and educational organizations of FSIN Russia, as well as in the educational work of correctional institutions. Variation can also have negative implications if it affects the accuracy of the use of scientific terminology.

We browsed the Scientific Electronic $\mathrm{Li}$ brary eLIBRARY.RU in order to find published researchby the keywords "criminal-executive doctrine" and "doctrine of the criminal-executive law", butthe search produced no results. At the same time, the key word "legal doctrine" is contained in 331 publications, and the key word "criminal-executive doctrine" (ranks second in the "rating" of keywords in combination with the term "legal doctrine") - in 30 publications. The term "penal doctrine", as a key word, is found in two publications [7; 15], and "penal science" in 19 publications. There is no term "correctional doctrine" as a keyword in eLIBRARY.RU, but it appears in the title of one of the publications [12].

All the above-mentioned terms ("criminalexecutive doctrine", "doctrine of the criminalexecutive law", "penal doctrine", "correctional doctrine") can be considered as synonymous if they are used as a means of expressing penal thought. However, there is a certain dualism here, because all of the terms, except for the "doctrine of the criminal-executive law", can be used as a means to express criminal-executive policy and reflect the main vector of state policy in the relevant field enacted in official documents. It is more logical to use the term "penal and legal doctrine" to objectify the fact of using penal and legal thought, becausein the framework of penal studiesone considers not only legal, but also sociological, psychological, pedagogical, and other issues.

There are no monographs that would study the term "penal and legal doctrine" and its synonyms, i.e. there has been no scientific research devoted to this category, its place in the conceptual series of legal categories, its functional content, theoretical and methodological significance, its relationship with adjacent concepts and categories, etc. In this article, we shall try and fill this gap in part.

It is important to emphasize that we are talking about the lack of development of the concept as a legal category rather than as a social phenomenon. Penitentiary science (doctrine) as a social phenomenon has been studied very carefully and its study continues with the efforts of a fairly wide range of penal scientists, and the quality of the findingsthey achieve is beyond doubt.

R.V. Puzikov [11], A.A. Zozulya [5], S.V. Baturina [2] and E.O. Madaev [8] studied the legal doctrine from the general theoretical positions. According to R.V. Puzikov, it is "a system of views developed by legal science on the problems of legal regulation of public relations, expressed in the form of principles, presumptions, axioms and other basic foundations; this system of views represents a model of positive law, serves as a regulator of public relations, determines priority directions, patterns and trends in the development of legislation, regardless of whether its provisions are legally established in any document" [11, p. 73]. Considering this definition from the perspective of constructive criticism, we would like to draw attention to the fact that the doctrine does not always act as a model of positive law, nor does it act as a regulator of public relations (norms of law act as such a regulator).

According to the viewpoint of A.A. Zozulya, "legal doctrine is a general legal category that integrates a set of legal and scientific interpretations and judgments of positive law, which develop and substantiate legal and cognitive forms of knowledge of law and legal phenomena, principles, concepts, terms, constructions, methods, means, techniques for understanding and interpreting positive law: its sources, systems, structures, actions and applications, violations and restoration" [5, p. 9]. This definition, in our opinion, is not an integrating one, i.e. it does not cover all the approaches that allow us to speak about the multiple contexts of the phenomenon under consideration.

We paid attention to the term "doctrine", which is generic to "penal and legal doctrine", when we came across the publications by Yu.E. Ibragimova, dedicated to the developmentof the concept "judicial doctrine". We should clarify that the practice of using the term "judicial doctrine" is not fragmentary, though it is not usedextensivelyin Russian legal science. It is used in foreign legal systems (primarily in 
the United States) as a means of generalizing judicial practice based on the principle of judicial precedent.

We believe that a legal doctrine cannot be tied to a specific professional community. We do not agree with Yu.E. Ibragimova's opinion that judicial doctrine and legal doctrine can be considered as two independent phenomena [6, p. 80]. Professional communities should be distinguished from scientific communities. Doctrine is the sphere of activity of the latter. Thus, when we speak about a "penal and legal doctrine", we mean the research findings of penal scientists outside of their official activities (and not all of them continue to serve in the penal system, and some have never experienced the burden of this service).

Earlier, one of the authors of the present paper drew attention to the fact that "the views of the category of legal practitioners who in the process of applying the law do not need deep reflexive thinking when making a law enforcement act can be described as corporate (corporate style of thinking)" [16, p.117-118].

In the framework of their professional duties related to the administration of justice, judges are not engaged in the formation of judicial doctrine, but in law enforcement and legal interpretation activities. At the same time, in some cases, they form their own legal positions rather than judicial doctrine. It is necessary to clearly distinguish between different types of activities. The activity of judges is not scientific, but professional. Granted, when they do not perform their professional duties, they can engage in doctrinal activities to increase scientific knowledge based, among other things, on the results of their practical activities, and these results will be objectified in scientific literature rather than in judicial acts. Thus, we can state the fact that various types of activities differ from each other by the sources of objectification of their results.

So, as we mentioned earlier, penal and legal doctrine is a means of expressing penal and legal thought. In this regard, the question arises about the relationship between the terms "science" and "doctrine". Not all authors consider them as similar. Thus, I.S. Zelenkevich draws attention to the difference between legal doctrine and legal science [4]. The differentiation of these terms occurs against the background of research on the problem of sources of law. This fact allows us to raise the question of recognizing the multiple contexts of the terms "legal science" and "legal doctrine". If they are considered in the context of using them as a form (source) of law, then the term "legal doctrine" looks more preferable, since it is more suited for the characteristic and form of expression of a certain legal position. Without going into further details, we believe that the term "legal position" would be more accurate to denote a scientific (doctrinal) view as a source of law. Legal science is very conservative in terms of the use of terminology, which obviously explains why the term "legal doctrine" is continued to be used for the purpose of designating a form of lawinstead of the term "legal position" that was introduced into scientific discourse mainly in the last decade.

E.O. Madaev highlights the scientific and applied nature of the latter and its focus on legal practice as an essential feature that distinguishes scientific research from doctrine [8, p. 56]. He suggests considering the legal doctrine as "a relatively independent, complex (multidimensional) element of the legal system of the state, which represents scientifically based, authoritative views and theories about other elements of the legal system and legal activity that have a scientific and applied nature and direct regulatory capabilities" [8, p. 61-62]. We believe that there are no prerequisites for giving the doctrine an applied character; rather, on the contrary, doctrinal specifics emphasize the predominance of the theoretical component over empiricism.

It is very problematic to distinguish between the notions such as "science" and "doctrine" in one plane. Scientific research cannot be considered as such if it ignores authoritative views and theories, and the applied nature is an obvious goal of any scientific research (although is it not always achievable), because science is aimed at "obtaining theoretical knowledge that serves to satisfy basic human needs" [13, p. 347]. However, the applied nature cannot be a constant companion of science. Some scholars see the meaning of its existence in the preemptive reflection of reality [3, p. 15].

Science is a field of activity, doctrine is a certain result of scientific activity that embodies not only knowledge, but can also be used as a means of knowledge. It is important to understand that not all the ideas that make up the "disciplinary matrix" of science are products of individual scientific thought bearing the name of its creator. Many things can be considered as animpersonal well-known result of collective efforts.

The term "doctrine" should also be distinguished from the term"concept". V.M. Baranov considers doctrine to be a category of "mainly or purely scientific creativity" [1, p. 54-56].

The practice of using theterm "doctrine"proves that it is in demand not only in science but 
also in the sphere of law-making; there, it denotesa normative strategic planning document (e.g., the information security doctrine approved by the President of the Russian Federation on September 9, 2000, No. Pr-1895). This highlights the multi-aspect nature of the term, but does not give rise to its "devaluation".

An important point in studying penal and legal doctrine is its differentiation from the science of criminal-executive law. The latter term is generic in relation to the former. The doctrine is more subjective, it makes it easier to reflect the opinion of individual scientists or their groups, but not the wholerange of penal scientists, which is usually not logical, since the unity of views in the scientific community on certain issues is not always achievable. No doubt, science gravitates toward collective forms of recognition, but against the background of individual creativity. This is one of its few strongholds remaining after the devaluation of the collective spirit. Doctrine "frames" the product of both collective creativity and individual achievements, if the latter are supported by a scientific school or scientific community working within a certain paradigm.

Legal doctrines can be classified according to various criteria. For instance, according to the content side, D.A. Polyanskii and R.V. Puzikov distinguish general legal doctrine, sectoral legal doctrine, and the doctrine of a specific legal institution [10]. In our opinion, it is not logical to talk about the doctrine of a specific legal institution, since such an approach devalues the term "doctrine", depersonalizes the result of the activity of a scholar or scholars. There should be a person behind this term - a scientist with a certain style of scientific thinking (metatheoretical baggage of knowledge).

Legal doctrine is a carrier of a certain legal ideology and a means of forming a legal policy. We share S.V. Baturina's view point, according to which "the legal doctrine, being the ideological basis of the Russian legal system, at the same time acts as a guiding vector for the development of legal policy" [2, p. 11].

An attempt to take a system-wide look at the phenomenon of penal and legal policy was made at the all-Russian round table held at Samara Institute of Law on December 12, 2013 [9]. In scientific publications, the terms "penal policy" and "criminal-executive policy" are used more frequently. In the titles of articles and in the keywords, they were used in 214 and 407 publications, respectively. These are more capacious (broad) terms that reflect changes and trends not only in law, but also in other fields, which is obviously more convenient when covering the relevant segment of public relations.
A.V. Mal'ko understandspenal and legal policy as a "scientifically substantiated, consistent and system-wide activity of state bodies and civil society institutions to optimize the penal system and improve the mechanism of penal and legal regulation" [9, p. 106]. Speaking about the need to create a concept for penal and legal policy, A.V. Mal'ko uses the term "doctrinal document" [9, p. 107]. But we believe that the document cannot be doctrinal. A doctrine is "a teaching, a scientific or philosophical theory, a political system, a guiding theoretical or political principle" $[14$, p. 211]. When we speak about documents, we find it more logical to use terms such as guiding, basic, directive, conceptual, etc.

We consider it possible to emphasize the influence of penal and legal doctrine on penal and legal policy by including this fact in our own definition as one of its essential features. Here it is necessary to pay attention to the fact that penal and legal doctrine acts as a metalanguage means of forming a criminal-executive policy. Its cognitive tools cover not only the theoretical but also the metatheoretical level of scientific knowledge - the style of legal thinking, legal paradigms, legal worldview, etc. This makes it possible to use the tools of interdisciplinary interaction when forming a penal and legal doctrine.

Our study produced the following findings.

The science of criminal-executive law needs self-cognition using general scientific knowledge and philosophical foundations. This is necessary for the systematization of scientific knowledge within a particular field. Systemwide nature of knowledge is one of the criteria for its validity. One of systematization tools is the doctrine as a system of views. The term "penal and legal doctrine" is a system-forming one and is a necessary prerequisite for carrying out scientific analysis.

We propose the following correlation between the terms "science" and "doctrine": science defines primarily the sphere of activity, and doctrine is a certain result of scientific activity, which not only embodies knowledge, but also can be used as a means of knowledge. It is more logical to use the term "doctrine"to personalize scientific views.

Let us formulate some recommendations on the use of the term "doctrine" in the penal sphere:

- proceeding from the fact that the term "science of criminal-executive law" is generic in relation to the term "penal and legal doctrine", we consider it advisable to use the latter to reflect the views of individual scientists or their groups, rather than the entire range of penal scientists; 
- it would be logical not to use the phrase "doctrinal document", but to use the terms "guidance document", "main document", "policy document", "framework document".

Concluding our study of the penal and legal doctrine as a legal category, we put forward our own definition of this category: it is a phenom- enon used in multiple contexts and reflecting formal aspects of penal science (as its source) and its content (as a system of views, a means of expressing penal thought), which acts as a carrier of a certain penal and legal ideology and a metalanguage means of forming the penal and legal policy.

\section{REFERENCES}

1. Baranov V.M. Kontseptsiya zakonoproekta: ucheb. posobie [Concept of a draft law: textbook]. Nizhny Novgorod, 2003. $190 \mathrm{p}$.

2. Baturina S.V. Traditsii rossiiskoi pravovoi doktriny. Avtoref. dis. ... kand. yurid. nauk [Traditions of Russian legal doctrine: Candidate of Sciences (Law) dissertation abstract]. Krasnodar, 2008. 27 p.

3. Berkov V.F. Filosofiya i metodologiya nauki: ucheb. posobie [Philosophy and methodology of science: textbook]. Moscow: Novoe znanie, 2004. $336 \mathrm{p}$.

4. Zelenkevich I.S. Legal doctrine and legal science: some aspects of correlation and use as sources of law. SeveroVostochnyi nauchnyi zhurnal = North-Eastern Scientific Journal, 2010, no. 2, pp. 42-47. (In Russ.).

5. Zozulya A.S. Doktrina v sovremennom prave. Avtoref. dis. ... kand. yurid. nauk [Doctrine in modern law: Candidate of Sciences (Law) dissertation abstract]. Saint Petersburg, 2006. $31 \mathrm{p}$.

6. Ibragimova Yu.E. The role of judicial doctrines in establishing and elimination of gaps in legislation. Zhurnal rossiiskogo prava = Journal of Russian Law, 2019, no. 11, pp. 80-95. (In Russ.).

7. Korsakov K.V. Alternatives to deprivation of liberty as a way out of the crisis of modern penal practice. Pravookhranitel'nye organy: teoriya i praktika = Law Enforcement Agencies: Theory and Practice, 2018, no. 1, pp. 23-26. (In Russ.)

8. Madaev E.O. Doktrina v pravovoi sisteme rossiiskoi federatsii. Diss. ... kand. yurid. nauk [Doctrine in the legal system of the Russian Federation: Candidate of Sciences (Law) dissertation]. Moscow, 2012. 254 p.

9. Mal'ko A.V., Romashov R.A., Timofeeva E.A. Penal and legal policy of Russia: constitutional foundations (review of materials of an all-Russian round table) (Samara, December 12, 2013).Gosudarstvo i pravo = State and Law, 2014, no. 12 , pp. 106-114. (In Russ.).

10. Polyanskii D.A.,Puzikov R.V. Legal doctrine as a special legal phenomenon.Vestnik TGU = Tambov University Review, 2013, no. 11 (127). Available at: https://cyberleninka.ru/article/n/pravovaya-doktrina-kak-osoboe-pravovoe-yavlenie (accessed July 1, 2020). (In Russ.).

11. Puzikov R.V. Yuridicheskaya doktrina v sfere pravovogo regulirovaniya (problemy teorii i praktiki): dis. kand. yurid. nauk [Legal doctrine in the sphere of legal regulation (problems of theory and practice): Candidate of Sciences (Law) dissertation]. Tambov, 2003. $196 \mathrm{p}$.

12. Seliverstov V.I. Correctional doctrine and its impact on the status of an individual exonerated from serving their sentences. Yuridicheskii vestnik Samarskogo universiteta = Juridical Journal of Samara University, 2018, no. 2, pp. 65-73. (In Russ.).

13. Kuznetsov V.G. (Ed.). Slovar' filosofskikh terminov [Dictionary of philosophical terms]. Moscow: INFRA-M, 2004. 731 p.

14. Sovremennyi slovar' inostrannykh slov [Modern dictionary of foreign words]. Moscow: Rus. yaz., 1993. 740 p.

15. Teplyashin P.V. Theoretical foundations of modern comparative research on European penal systems. Sovremennoe pravo = Modern Law, 2015, no. 1, pp. 112-116. (In Russ.).

16. Shakhanov V.V. "Horizontal" and "vertical" structuring of elements of the legal system as a reflection of its metaphenomenality (revisiting the issue of conceptual series of legal categories). Pravovaya politika i pravovaya zhizn' = Legal Policy and Legal Life, 2019, no. 2, pp. 114-119. (In Russ.).

\section{INFORMATION ABOUT THE AUTHORS}

VITALII E. LAPSHIN - Doctor of Sciences (Pedagogy), Candidate of Sciences (Law), Associate Professor, professor of the Department of Personality Psychology and Special Education at Vladimir State University Named After Alexander and Nikolay Stoletovs, Vladimir, Russian Federation, professor of the Department of Psychology and Pedagogy of Professional Activity at Vladimir Law Institute of FSIN Russia, Vladimir, Russian Federation, professor of the Department of Legal Psychology and Pedagogy at Vologda Institute of Law and Economics of FSIN Russia, Vologda, Russian Federation. ORCID: https://orcid.org/0000-0002-6243-9532, e-mail:ve_lapshin@mail.ru

VYACHESLAV V. SHAKHANOV - Candidate of Sciences (Law), associate professor of the Department of Theory and History of State and Law at Vladimir Branch of the Russian Academy of National Economy and Public Administration under the President of the Russian Federation, Vladimir, Russian Federation, associate professor of the Department of Public Law Disciplines of the Faculty of Law and Management at Vladimir Law Institute of FSIN Russia, Vladimir, Russian Federation. ORCID: https://orcid.org/0000-0003-1251-7886, e-mail: shakhanov.vyacheslav@mail.ru 